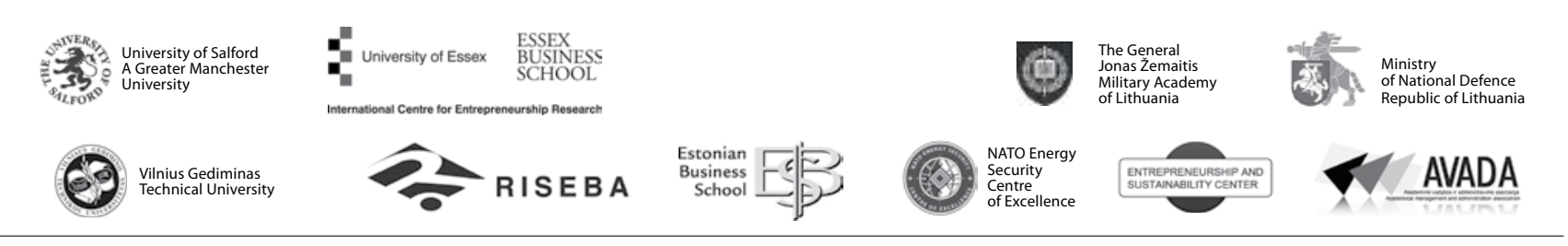

\author{
JOURNAL OF SECURITY AND SUSTAINABILITY ISSUES \\ ISSN 2029-7017 print/ISSN 2029-7025 online \\ 2018 June Volume 7 Number 4 \\ https://doi.org/10.9770/jssi.2018.7.4(3)
}

\title{
SECURITY, SURVEILLANCE AND RE-SOCIALIZATION ASPECTS IN CENTER FOR DRUG ADDICTS OF OLAINE CITY PRISON IN LATVIA
}

\author{
Vitolds Zahars', Maris Stivrenieks ${ }^{2}$ \\ ${ }^{1,2}$ Daugavpils University, Parades st. 1, Daugavpils, LV-5401 Latvia \\ E-mails: ${ }^{1}$ vitolds.zahars@inbox.lv, ${ }^{2}$ maris.stivrenieks@inbox.lv \\ Received 10 January 2018; accepted 15 May 2018
}

\begin{abstract}
Drugs and prison - this consistent pattern is often undeniable. It is undeniable that most of those people who end up in prison, have used narcotic or psychotropic substances before. The use of substances that causes addiction and the development of addiction is influenced by a number of different factors; in some cases, by the imprisonment itself. The authors of the article offer, continuing with scientific publication cycle, which is dedicated to execution of sentence of imprisonment in Latvia and security aspects of the places of confinement, to become familiar with the study about peculiarities of execution of the sentence of imprisonment and security aspects at the newly established Center for drug addicts of Olaine city prison, where convicted persons, during the serving of a sentence, are involved in addiction reduction programs. The aim of the execution of the sentence of imprisonment is to effectively apply all conditions of the sentence execution in respect of the convicted person, thus ensuring re-socialization of a person and the legal behavior of a person after execution of the sentence. However, it is undeniable that only those persons, who are free from narcotic or psychotropic substances addiction can be re-socialized; therefore, the study obtains the status of vitally important topicality. This article reflects the results of the conducted study about peculiarities of execution of the sentence of imprisonment at the Center for drug addicts of Olaine city prison. The article identifies issues and suggests possible solutions. Based on the study there has been developed a series of recommendations for the staff of the places of confinement working with convicted drug addicts. The authors suggest that the drawbacks and issues discovered within the framework of this study, as well as proposed solutions, will make a significant contribution to the development of the penalty execution theory in Latvia. It will be possible to improve the sentence of imprisonment execution legal framework and practice by using new scientific cognitions stated in this study.
\end{abstract}

Keywords: imprisonment, execution of the sentence, convicts, security, re-socialization, addiction reduction program.

Reference to this paper should be made as follows: Zahars, V.; Stivrenieks, M. 2018. Security, surveillance and resocialization aspects in center for drug addicts of olaine city prison, Journal of Security and Sustainability Issues 7(4): 643-656. https://doi.org/10.9770/jssi.2018.7.4(3)

JEL Classifications: K1, K14, N43

\section{Introduction}

The use of substances that cause addiction and the development of addiction are influenced by a number of different factors. Apart from objective features (age, gender, type of the populated area, etc.) there are a number of individual psychological and subjective factors that encourage or hinder desire to try the substances and the use of substances. One of the strongest risk factors and at the same time one of the strongest protective factors are the individual qualities and values (Koroleva et al, 2007; Matvejevs 2018). 
Drugs and prison - this consistent pattern is often undeniable. It is undeniable that most of those people who end up in prison, have used narcotic substances before. Losing freedom in Latvia is just like a side-effect of a narcological disease that has not been timely prevented. However, isolation from society by itself is not a cure for this disease (Luste 2016).

The authors of the article offer, continuing with scientific publication cycle, which is dedicated to execution of sentence of imprisonment in Latvia and security aspects of the places of confinement, to become familiar with the study about peculiarities of execution of the sentence of imprisonment and security aspects in the places of confinement in respect of convicted persons, who are serving their sentence at the Center for drug addicts of Olaine city prison, and who are involved in addiction reduction programs. Readers can get acquainted with authors' earlier scientific publications, which are dedicated to peculiarities of execution of the sentence of imprisonment and security aspects in the places of confinement in respect of convicted women, convicted minors and the persons sentenced with deprivation of liberty for life, in the following journals: Journal of Security and Sustainability Issues Nr.3(3), 2014, Journal of Security and Sustainability Issues Nr.4(3), 2015 and Journal of Security and Sustainability Issues Nr.6(1), 2016.

This article reflects the results of the conducted study about peculiarities of execution of the sentence of imprisonment in respect of convicted persons, who are serving their sentence at the Center for drug addicts of Olaine city prison, and who are involved in addiction reduction programs in Latvia. This article examines peculiarities of execution of the sentence of imprisonment at the Center for drug addicts of Olaine city prison, as well as identifies issues and suggests possible solutions.

On October 5, 2016 a new Center for drug addicts, governed by the administration of the places of confinement, was opened in Olaine city prison, which is a structural unit of the Olaine city prison. The Center for drug addicts of Olaine city prison is intended for convicted persons, who suffer from narcotic or psychotropic substance addiction, with the aim of reducing and minimizing and eradicating the risk of addiction of these individuals and teaching them to live with this addiction problem when returning from the imprisonment into society. At the same time, it should be noted that only addiction-free convicts can be fully involved in the re-socialization process. L. Medina, the Deputy of the State Secretary of the Ministry of Justice, acknowledged that if we do not work with these addictions, then nothing else will affect this person, neither schooling nor acquisition of new work skills. Unfortunately, our past efforts to prevent addiction in the places of confinement (mainly due to lack of finance) have been extremely fragmentarily (Luksa 2015).

\section{The Center for drug addicts of Olaine prison (Latvian Prison Hospital): a new philosophy of execution of the sentence of imprisonment}

The project that was started already on September 18, 2013, was the plan of the administration of the places of confinement to create conditions for intensive re-socialization of prisoners, who suffer from drug addiction. According to the administration of the places of confinement, within the framework of this project, for this purpose, the methodology was borrowed (and customized to local conditions), which has been approved in the prisons of Norway and Poland; prison staff trainings were organized, as well as other activities were performed for the establishment of a drug addict re-socialization system within the conditions of confinement. 200 drug addicted imprisoned persons are to be placed in the Center at the same time. Until now, due to the outdated infrastructure in Latvian prisons, it was problematic to ensure the isolation (a safe environment) of the imprisoned drug addicts from narcotic and psychotropic substances, as well as to provide preconditions for resocialization work with special target groups. When initiating the re-socialization of persons, who suffer from drug addiction, it is necessary to close all access pathways to the addictive substances. Their movement outside the department should be limited and controlled.

The authors of the study completely agree with the stated conclusion the prevalence of drug use depends on the availability of narcotic substances to the public. The easier it is to get drugs, the greater the risk that they will be used (Koroleva, Mierina, Goldmanis, Trapencieris 2008). According to the public report data of the administra- 
tion of the places of confinement, in 2017, 1684.7753 grams of narcotic and psychotropic substances and 1194 tablets containing narcotic and psychotropic substances were taken out of the places of confinement of Latvia.

It is worth reminding that the study data obtained in 2014 suggests that the imprisonment, in all respects, has a more contributing rather than refraining effect in respect of drug use. According to the study, regardless of the experience of use of narcotic and psychotropic substances, $42 \%$ of convicted persons have confirmed that if they used drugs before the imprisonment, they will continue using them in the place of confinement. Study data also indicate that $19 \%$ of convicts start using narcotic substances precisely during the imprisonment.

Addiction is a biopsychosocial disease, that results in functional and later also organic disorders in the functioning of the human body, the change of way of thinking, the content, and the change of style of work associated with the perception of new information, the ability to recognize emotions and expression types. In view of the above, it can be concluded that addiction is a disease during which an individual is unable to control the use of psychoactive substances or these substances negatively affect his/her behavior. The psychoactive substances and inability to control one's behavior, in their turn, are among the most common causes of commitment of criminal offenses.

In 2014, a study conducted in Latvia also found that during the last year $89 \%$ of convicts used alcoholic beverages before the imprisonment. More than half of those convicted persons (55\%) used alcohol quite often $28 \%$, they used it 1-2 times a week, and $27 \%-3$ times or more per week. The convicted users of psychoactive substances experience the greatest feeling of discomfort and a feeling of "unfreedom" not from the fact of isolation itself, but rather from their bad habits - alcohol, narcotic, psychotropic or toxic substance addiction. The study found that $85 \%$ of convicts in the places of confinement of Latvia suffer from addiction, which makes it harder for them to be included in social activities (Klave, Bebrisha, Zhabko, Shupule, Jansone 2014).

Prison should be the kind of institution that helps the addicts to get rid of addiction, which caused these persons to end up in prison in the first place. It follows that, for the sake of public safety and other socially important objectives, the overarching tasks of the Center for drug addicts of Olaine city prison should be as follows:

a) to create an appropriate social environment in which clients would be denied any access to psychoactive substances;

b) to involve clients in social behavior correction programs, to develop their positive social skills and abilities, to learn and respect the values that are recognized in society;

c) to reduce the risk of repeated criminal offenses.

According to M. Luste, the leader of this project, nowadays a new prison philosophy is emerging as compared to what we inherited from the Soviet times. It might seem like this project is just a work with yet another target group. However, in reality, I see it as a restart test of all the system of the places of confinement, introducing a new philosophy in respect of prisoner care (Luste 2014).

According to the data provided by the administration of the places of confinement, for March 6, 2018, 48 convicts of the Center for drug addicts of Olaine city prison were involved in addiction reduction programs, however since September 1, 2017, the convicted women can also be included in addiction reduction programs of this Center. A woman being in prison is an anomaly, but it is well known fact that the number of female prisoners around the world is increasing. Unfortunately, it must be noted that a large proportion of convicted women have had some sort of encounter with drug or alcohol problem. Drug use among women is increasing and the increased drug use means that the majority of these women will end up in prison (Zahars, Stivrenieks 2015). In its turn, the involvement of minor convicts in these programs could start in 2018 , for the analysis of the components of crime of the criminal offenses committed by minors shows that the criminal offenses committed by minors are becoming more aggressive, more brutal and better planed, and are often directly or indirectly related to alcohol, psychotropic or narcotic substance abuse (Zahars, Stivrenieks 2014).

The fifth part of the Section 18 of Law On The Sentence Execution Code of Latvia provides that convicted 
persons, who are involved in re-socialization program for reduction of addiction shall be held separately from other convicted persons in conformity with the provisions of the first part of this Section, and the first part of the Section $61 .^{8}$ of Law On The Sentence Execution Code of Latvia provides that a convicted person can be involved in the addiction reduction program if there is a high risk that he or she may start using alcohol, narcotic, psychotropic or toxic substances. The addiction reduction program lasts up to 12 months and is implemented by ensuring the isolation of convicts, involved in the program, from other convicts during the whole program implementation period. According to I. Spure, the head of the administration of the places of confinement, the work and life of prisoners in this center are based on the principle of the therapeutic community, and one prison unit is provided only for 24 prisoners, who during the training, are divided into 12 persons. The new infrastructure allows the prison to execute this program. The prison staff works in accordance with the "contact person principle". Employees carry out both support and control functions. Unlike the usual model, each convict is assigned a support person om among employees, which allows for a more personalized approach to re-socialization (Paparde 2016).

This center offers 2 to 12 months long re-socialization programs, that are currently intended only for adult prisoners. Programs are aimed at reducing addiction, but they are not therapeutic programs. Both programs are specifically designed to reduce the addiction of adult prisoners. One of the treatment programs is based on the Norwegian experience of treatment of addiction - "Atlantis", which focuses on the study of the past, and the ability to understand the causes of addiction, which includes several tasks that have to be completed in order to achieve the set goal. It teaches the convicts to acquire social skills, to plan and to structure their life, to change their way of thinking and behavior, and the other program - "Pathfinder" is based on the experience of the Polish prison system; it is focused on the future, the development of social skills, the restructuring of life and normal functioning without the need for addictive substances; it is based on the physical, psycho-social and spiritual aspects, where the method of cognitive - behavioral therapy and social training are the dominant factors. The Center for drug addicts is the institution in which it is possible to prevent the endogenic and exogenous causes and the contributing factors of new criminal offenses. The work organization of the institution is based on the principles of psychotherapeutic community, which have been tested in many places in the world and have been recognized as the most effective way to free the clients from addiction who participate in this program. Setting a goal to prevent crime, one must be aware that its implementation is possible only by moving toward it from two directions: firstly, by transforming the social environment and eliminating the exogenous factors of crime; secondly, by transforming the personality of the offender and eliminating endogenous factors, by the influence of which the individual has committed a criminal offense (Zahars 2017).

\section{Procedure for addition of convicted persons in addiction reduction programs}

Convicted persons are being involved in addiction reduction programs only on a voluntary basis. According to I. Ushacka, the head of the Center for drug addicts, the issue of how to choose the clients of the new center is not simple. Application for re-socialization program at the Center for drug addicts of Olaine city prison is the voluntary choice of prisoners; the same as with electronic cuffs. So far, prisoners were not particularly eager to participate in re-socialization programs. Although the living conditions in the Center for drug addicts of Olaine city will be good and exemplary - there are also pleasant advantages, it is also clear that the treatment process is no fun. You cannot force anybody to do anything, especially the drug addicts (Luksa 2015).

The second part of the Section $61 .{ }^{8}$ of Law On The Sentence Execution Code of Latvia provides that the convict who wishes to participate in the addiction reduction program shall submit a corresponding application to the head of the place of confinement. Taking into account the assessment of the risks and needs of the convicted person, the head of the place of confinement shall draw up a proposal regarding the involvement of the convict in the addiction reduction program and shall send it to the head of the administration of the places of confinement. The head of the administration of the places of confinement, having evaluated the proposal of the head of the places of confinement, makes a decision regarding the involvement or refusal to involve the convict in addiction reduction program, or decides to postpone the convicted person's involvement in the addiction reduction program, and informs about it the head of the place of confinement and the convicted person in writing. 
The proposal of the head of the places of confinement to involve the convict in addiction reduction program or the refusal to prepare such proposal, and the decision of the head of the administration of the places of confinement regarding the involvement or refusal to involve the convict in addiction reduction program, or the decision to postpone the convicted person's involvement in the addiction reduction program cannot be challenged or appealed.

The internal order in the unit of the place of confinement, where the addiction reduction program is implemented, is stipulated by the Regulations No.23 "The rules of internal order in the division of the place of confinement where the re-socialization program is implemented for the reduction of addiction" of the Cabinet of Ministers as of January 3, 2017. The authors of the study, having analyzed the norms of the Law On The Sentence Execution Code of Latvia and the norms of the above-mentioned Regulations of the Cabinet of Ministers, conclude that, despite the fact that the paragraph 2 of the Regulations No.23 "The rules of internal order in the division of the place of confinement where the re-socialization program is implemented for the reduction of addiction" of the Cabinet of Ministers as of January 3, 2017 provides that convicts involved in the addiction reduction program are not subject to the general provisions of the internal order of the place of confinement, however such requirement does not follow from what is stated in the Law On The Sentence Execution Code of Latvia.

The paragraph 16 of the Regulations No.23 "The rules of internal order in the division of the place of confinement where the re-socialization program is implemented for the reduction of addiction" of the Cabinet of Ministers as of January 3, 2017 provides that the daily regimen of the convicted persons at the Center for drug addicts is determined by the order of the head of the Olaine city prison. The daily regimen of the convicted persons includes a number of daily activities, i.e.: re-socialization and regime activities, convicted persons' mealtimes, daily walks, rest time, convicted persons' visiting hours, time for telephone conversations, as well as an uninterrupted eight-hour sleep. In addition to the above, it is useful to note that convicted persons, who involved in addiction reduction programs at the Center for drug addicts of Olaine city prison, are checked daily with rapid tests in order to determine whether they have used narcotic or psychotropic substances. This type of control plays both a practical and a preventive role in the fight against addiction. In turn, according to the paragraph 22.12. of the Regulations No.23 "The rules of internal order in the division of the place of confinement where the re-socialization program is implemented for the reduction of addiction" of the Cabinet of Ministers as of January 3, 2017, a convict who is involved in the addiction reduction program, is obliged to undergo a test in order to determine whether the convict has used alcohol, narcotic, psychotropic or toxic substances. The refusal to undergo such testing is considered to be a disciplinary infraction. Psychologist V. Semenkova believes that when determining rules of the regime of convicted persons, they must be psychologically substantiated and psychologically purposeful, so that the organization of life and activity of the convicts would comply with the relevant scientific requirements. The rules maximally affect the convicted persons' psyche, developing the necessary moral and psychological characteristics. The use of psychological data allows us to create a regime in such a way as to optimize the distribution of the load: on the one hand, to create a certain load that has a positive effect on the development of a personality, but, on the other hand, would also create motivation for others (Semenkova 2001).

\section{The regime of execution of sentence of imprisonment as an integral part of addiction reduction programs}

Rule 36 of the "Standard Minimum Rules for the Treatment of Prisoners" (the Nelson Mandela Rules), approved by the United Nations General Assembly as of December 17, 2015, provides that discipline and order shall be maintained with no more restriction than is necessary to ensure safe custody, the secure operation of the prison and a well-ordered community life. The paragraph 102.1 of the Recommendation Rec (2006)2 of the Committee of Ministers to member states on the European Prison Rules of the Council of Europe provides that in addition to the rules that apply to all prisoners, the regime for sentenced prisoners shall be designed to enable them to lead a responsible and crime-free life, and the paragraph 102.2. of these Recommendation provides that imprisonment is by the deprivation of liberty a punishment in itself and therefore the regime for sentenced prisoners shall not aggravate the suffering inherent in imprisonment. It must be acknowledged that in Latvia criminal punishment policy is in the process of transition to European and democratic values (Stivrenieks 2016). 
The requirements of the regime of execution of sentence of imprisonment in the Center for drug addicts is stricter regarding certain issues than those applied in respect of convicts of closed and partly-closed prisons. The paragraph 21 of the Regulations No.23 "The rules of internal order in the division of the place of confinement where the re-socialization program is implemented for the reduction of addiction" of the Cabinet of Ministers as of January 3, 2017 provides that the convicts placed in the Center for drug addicts only have the following rights: to keep in the living accommodation the items necessary for personal use in the assortment and quantity specified by these provisions. The total weight of the items that a convicted person is allowed to keep in the living accommodation of the Center for drug addicts shall not exceed 15 kilograms. The total weight of the personal items of a convicted person in the Olaine city prison shall not exceed 30 kilograms. The convicted person has the right to address the head of the Olaine city prison by submitting a written application requesting permission to be allowed to keep religious items and literature. The convicted person has the right to be accepted by employees at the appointed time according to the daily plan. At the request of the convicted person, he may be admitted without the presence of other persons. The convicted person has the right to ask for a chaplain, so that he would invite a clergyman of convicted person's denomination, as well as the right to address the head of the Olaine city prison by submitting an application regarding the termination of the agreement mentioned in this provision. The convicted person has the right to smoke at the stipulated place and time. In addition to the above, the paragraph 22 and 23 of the Regulations No.23 "The rules of internal order in the division of the place of confinement where the re-socialization program is implemented for the reduction of addiction" of the Cabinet of Ministers as of January 3, 2017 provides a number of obligations and prohibitions.

The ninth part of the Section 70 of Law On The Sentence Execution Code of Latvia provides that for violation of the requirements of the sentence serving regime the following punishments may be imposed on convicted persons, who are involved in the addiction reduction program: the giving of a warning, the giving of a reprimand, the prohibition to purchase food products and tobacco products in the shop of a deprivation of liberty institution for a time period up to one month, the prohibition of the next visit by relatives and other persons, placing convicted persons who are serving sentences in prisons in a punishment isolation cell for a time period up to fifteen days and nights or placing convicted persons in a disciplinary isolation cell for a time period up to ten days and nights, canceling pre-assigned encouragement. With regard to convicts involved in addiction reduction programs in the Center for drug addicts, the norms of The Sentence Execution Code of Latvia do not provide such disciplinary punishments as: the prohibition to use a personal TV set or a transistor radio, the prohibition to the current telephone call or a video call.

In addition to the above, it is useful to point out that in practice the disciplinary punishment - placing convicted persons in a disciplinary isolation cell is applied very rarely and only in a case of extreme necessity, because placing the convicted person into isolation cell for a time period up to fifteen days would significantly delay the acquisition of the addiction reduction program requirements. The first part of the Section 45 of Law On The Sentence Execution Code of Latvia provides that the persons sentenced with deprivation of liberty, except persons, who are involved in the addiction reduction program, and the convicted persons who are sentenced with temporary deprivation of liberty, shall have an opportunity to meet their relatives and other persons without the presence of a representative of the deprivation of liberty institution in accordance with the procedures and extent laid down in this Code: short visits - from one to two hours in order to facilitate the maintaining and renewal of socially useful contacts; long visits - from six to forty-eight hours in order to facilitate the maintaining of kinship and family contacts, and the sixth part of the Section $61 .^{8}$ of Law On The Sentence Execution Code of Latvia provides that the convicted persons, who involved in the addiction reduction program, may be visited by relatives and other persons with the presence of a representatives of the deprivation of liberty institution, once a month, from one to six hours, in order to facilitate the maintaining and renewal of socially useful contacts.

The authors of the study, having analyzed the extent of the rights with regard to convicted persons, who are serving a sentence of imprisonment in the Center for drug addicts, which is provided in the first part of the Section 45 and the sixth part of the Section $61 .^{8}$ of Law On The Sentence Execution Code of Latvia, have established that these convicted persons are not entitled to meet relatives and other persons in accordance with 
the usual order. The norms of the Law On The Sentence Execution Code of Latvia precisely stipulate that those convicted persons, who are involved in re-socialization programs, may be visited by relatives and other persons once a month or they may be denied visitation right by the prison administration.

In the light of the above, the authors of the study point out that this practice may, to a certain extent, contravene the Recommendation Rec (2006) 2 of the Committee of Ministers to member states on the European Prison Rules of the Council of Europe. The paragraph 24.1., 24.2. and 24.4. of the European Prison Rules points out that prisoners are allowed to meet with their family members and other persons as often as possible. It is also emphasized that despite the existing restrictions and control, a minimum level of communication must be ensured so that prisoners would be able to strengthen their family relationships in the most normal circumstances.

The authors of the study also point out that convicts, who are involved in addiction reduction programs, unlike the convicts of closed and partly-closed prisons, do not have the right to receive personal clothing and other items and belongings in accordance with the Regulations No.423 "The Rules of Internal Order of Penitentiary Institutions" of the Cabinet of Ministers as of May 3, 2006, but the paragraph 48. of the Regulations No.23 "The rules of internal order in the division of the place of confinement where the re-socialization program is implemented for the reduction of addiction" of the Cabinet of Ministers as of January 3, 2017 provides that the convicted persons of Olaine city prison wear season-appropriate headgear, footwear and clothing with an identification badge provided by Olaine city prison. In reality, the Regulations No.23 of the Cabinet of Ministers as of January 3, 2017 are violated, as a result of which the persons, who are involved in the re-socialization programs to reduce addiction do not receive such clothing. Such practice does not comply with the requirements of international standards and norms, as well as the principles of good governance. From the foregoing, it can be concluded that the absence of uniform in the Center for drug addicts of Olaine city prison may create various risks for the overall security of this institution and impede the search of clients of this institution if they have arbitrarily left the territory of the institution.

\section{Security aspects of the Center for drug addicts of Olaine city prison}

The administration of the places of confinement is responsible for maintaining order at the place of confinement and for ensuring the safety of prisoners. Therefore, prison staff can impose disciplinary punishments and security measures in respect of prisoners and, in specific cases, use force, but always only in accordance with the law and strictly following the particular procedure. According to the former Minister of Justice, B. Broka, the prison employee should be aware that his work involves an increased level of risk, and therefore compliance with safety rules is absolutely mandatory and no deviation from it is allowed (Broka 2014).

The security aspects of the place of confinement in the Center for drug addicts are based on both the general safety and regime requirements, as well as by putting a dynamic security model into practice. Dynamic security is the regular and consistent interaction with offenders and the timely exchange of information. The principles of dynamic security are professionalism, understanding of the situation of convicted persons, positive and friendly relations, strictness, but also justice and information exchange between all employees of the institution. Good interna01 order and the highest level of security at the place of confinement can be achieved when the officials responsible for security, surveillance and re-socialization cooperate with each other rather than compete or dominate one another and share information rather than conceal it (Zahars, Stivrenieks 2015).

In order to maintain good order, the Council of Europe recommends focusing on dynamic security, developing a positive relationship between the prison staff and the prisoners, based on strictness and justice, combining it with an understanding of the personal situation of convicted persons. This requires: the long-term interaction between prisoners and prison staff, especially in the context of activities, mechanisms for resolving disputes with and between prisoners by way of reconciliation, and the opportunity for prisoners to play an active role and make personal decisions in the daily life in prison, entrusting them with as wide a range of issues as possible (Cretenot 2013). 
The first part of the Section $13 .^{2}$ of Law On The Sentence Execution Code of Latvia provides that the commission responsible for placement of convicts, which is established by the order of the head of the place of confinement, shall determine in which section, division and cell of the place of confinement the convicted person will be placed, taking into account free space in cells, psychological compatibility of convicted persons, state of health, attitude towards smoking and previous criminal experience, the fifth part of the Section 18 of The Sentence Execution Code of Latvia, in its turn, provides that convicted persons, who are involved in the resocialization program for reduction of addiction shall be held separately from other convicted persons. In practice, the convicted persons, who are involved in addiction reduction programs at the Center for drug addicts, are placed (one or two persons) in a two-place cells. The convicted persons are placed in divisions (rooms), by observing the commune principle, which means that all the convicts in the divisions participate in solving everyday household issues. In this way, the social communication and the culture of relationships of the convicts is renewed. The first part of the Section 47. ${ }^{1}$ of Law On The Sentence Execution Code of Latvia provides that Convicted persons shall be permitted to use TV sets and transistor radios (without the possibilities of voice recording) of the deprivation of liberty institution and personal TV sets and radio receivers (without the possibilities of voice recording), as well as other personal household appliances, at the time and in accordance with the procedures laid down in the internal procedural regulations of the deprivation of liberty institution, and the third part of this Section provides that the rights set out in part one of this Section do not apply to convicts, who are involved in the addiction reduction program. The convicts, who are involved in the addiction reduction program are allowed to use, in common areas, TV sets and transistor radios (without the possibilities of voice recording) of the deprivation of liberty institution, in accordance with the agenda established by the head of the deprivation of liberty institution. Such a ban in respect of convicts, who are involved in an addiction reduction program is intended to prevent the transmission of narcotic, psychotropic or other intoxicating substances through the supply of household appliances to the Center for drug addicts. It is no secret that convicted persons use all the possibilities to get into the places of confinement not only intoxicating substances, but also other items that are prohibited in the places of confinement. According to the report (2017) data of the administration of the places of confinement, in 2017, 2284 mobile phones, 905 cell phone components, 1772 mobile phone SIM cards, 199 syringes, 168 syringe needles, 1431 self-made cutting and piercing objects were removed from the places of confinement of Latvia.

The first part of the Section 49. ${ }^{2}$ of Law On The Sentence Execution Code of Latvia provides that a convicted person who is serving the sentence at the highest level of the sentence serving regime in a partly-closed prison, an open prison or a juvenile correctional institution may, by lodging a written submission to the head of the deprivation of liberty institution, request a permission to temporarily leave the deprivation of liberty institution for up to five twenty-four hour periods due to death of a close relative or a serious illness that endangers the life of a sick person, and the eleventh part of this Section provides that the information mentioned in this Section in respect of the right of a convicted person to request a permission to temporarily leave the deprivation of liberty institution does not apply to convicted persons, who are involved in an addiction reduction program, except when it is provided for in the conditions of an addiction reduction program. The convicted persons, who are involved in the addiction reduction program may exercise the right to leave the deprivation of liberty institution only in the presence of an official of the deprivation of liberty institution and for a period of up to eight hours.

The authors of the study, in their analysis of the practice, have found that convicts, who are involved in the addiction reduction program are given the opportunity to take a temporary vacation outside the place of confinement, but these convicted persons may leave the prison territory only for a specific purpose and always accompanied by the employees of the place of confinement. The purposes for leaving the territory of the place of confinement in practice are different. They are related both to resolving of social problems of the convicts, the attendance of public institutions, and leisure activities, when convicted persons have the opportunity to visit museums, go hiking, or participate in other activities.

Leisure activities play an important role during the period of execution of the sentence of imprisonment, especially in respect of convicted persons, who suffer from addiction to different intoxicating substances. The paragraph 27.6. of the European Prison Rules provides that Recreational opportunities, which include sport, games, 
cultural activities, hobbies and other leisure pursuits, shall be provided and, as far as possible, prisoners shall be allowed to organize them. During the execution of the sentence of imprisonment, it is very important that the opportunities of organized leisure activities are meaningful and substantial, aimed at creating positive values.

The sixth part of the Section $61 .^{8}$ of Law On The Sentence Execution Code of Latvia provides that who involved in the addiction reduction program, may be visited by relatives and other persons with the presence of a representatives of the deprivation of liberty institution, once a month, from one to six hours, in order to facilitate the maintaining and renewal of socially useful contacts. Based on the above, a new way to visit convicted persons was introduced at the Center for drug addicts - "Family Days". According to I. Ushacka, the head of the Center for drug addicts of Olaine city prison, the support and the meeting of relatives greatly "strengthens" both the center's clients and employees, and if a client is "strengthened", then he has a growing motivation to change. In their turn, for the center psychologists and client contact persons these meetings represent an opportunity to evaluate the growth of clients see new and positive aspects of their character, successfully using them in further collaboration with clients. This event is also very important to the relatives of convicted persons. The relatives of the convicted persons, who came to this event, have thanked the employees for a well-organized meeting and expressed their satisfaction at the humane attitude and psychological support, which they lack in society, as family members, especially children, are faced with daily intolerance and exclusion.

A serious threat to the security of the place of confinement is the presence of a criminal subculture in the place of confinement, and in particular a difficult situation may arise in the places of confinement where the prison administration supports this subculture. The opportunities that encourage the development of criminal subculture and violence exist in those places of confinement, where the convicts are still placed in old prison facilities, large and spacious rooms (units), where up to one hundred convicts can be present at the same time. The best solution for eliminating criminal subcultures in the places of confinement is the placement of convicted persons in small cells and an agenda consisting of positive and socially-beneficial activities (Zahars, Stivrenieks 2015).

The existence of prisoners' subculture in Latvian places of confinement cannot be denied. The subculture of prisoners is a complex system of prisoners' relations with the internal pyramid of power and self-created brutal justice inherited from the Soviet times. The fact of existence of subculture in Latvian places of confinement has also been recognized by the Supreme Court Senate in its judgment as of July 9, 2012, which states that the places of confinement have their own prisoner hierarchy or a caste system.

The Center for drug addicts of Olaine city prison plays an important role in the system of the places of confinement regarding reduction and elimination of the prisoner subculture. The subculture of prisoners does not exist and is not tolerated in the Center for drug addicts, thus the Center for drug addicts reduces the existence of prisoner subculture as such in places of confinement of Latvia.

\section{Exclusion from addiction reduction programs}

The convicted person is excluded from the addiction reduction program if:

1. the time set for implementing the addiction reduction program has expired;

2. the convicted person has reached the result specified in the re-socialization plan;

3. by convicted person's application;

4. the convicted person is released from serving the sentence.

In addition to the above, it is useful to point out that the convicted person may be excluded from the addiction reduction program following the decision of the head of the Center for drug addicts if:

1. the convicted person has committed a violation of the sentence serving regime;

2. the convicted person does not fulfill the conditions of the addiction reduction program;

3. due to the state of health the convicted person, cannot participate in the addiction reduction program;

4. the in-depth assessment of the risks and needs of the convicted person found that the convict does not meet any of the conditions of the implemented package of measures. 
In view of the above, a convicted person is excluded from the addiction reduction program on the basis of the decision of the head of Olaine city prison and:

1. according to the order of the head of the administration of the places of confinement the convicted person is transferred to another place of confinement to keep serving the sentence of imprisonment;

2. the convicted person is released from the sentence due to the expiry of the term of the sentence imprisonment;

3. the convicted person is released from serving the sentence of imprisonment before the appointed time, with or without electronic surveillance.

According to the statistical data of the administration of the places of confinement in 2017, the following number of persons was sent to the Center for drug addicts: 120 convicts (including 107 men and 13 women). In 2017, at the Center for drug addicts, 38 convicts have completed the "Atlantis" program, and 20 convicts have completed the "Pathfinder" program.

In 2017, 65 convicted persons were excluded from the Center for drug addicts, including: based on the application of the convicted person 12 (including convicts who refused to attend the Center for drug addicts prior to the commencement of the program) 18 of them did not fulfill the program conditions, 12 of them did not meet the conditions of the program, 1 of them violated the sentence execution regime, and 22 of them - due to the achievement of the results of the re-socialization plan.

The paragraph 138. of the Regulations No.23 "The rules of internal order in the division of the place of confinement where the re-socialization program is implemented for the reduction of addiction" of the Cabinet of Ministers as of January 3, 2017 provides that when transferring a convicted person to the place of confinement, who has completed an addiction reduction program in accordance with the results of the re-socialization plan, he is placed separately from convicts, who have not completed the addiction reduction program.

Based on the above, Daugavgriva, Liepaja and Jekabpils prisons were equipped with separate narcotic and psychotropic substance free units, where only those convicted persons are placed, who have successfully completed the addiction reduction program in the Center for drug addicts of Olaine city prison. Such isolation of convicts from the other convicts is done for two reasons: firstly, it is related to the application of the knowledge and skills acquired in addiction reduction programs, and, secondly, it is related to the general safety aspects of these persons. The persons, who have completed the addiction reduction program, after returning to the old prison infrastructure to serve their sentence, with their new behavioral model can have a positive effect on the microclimate and safety of the institution, as they will, with their positive example, create a favorable soil for other prisoners to quit the use of narcotic substances in their future lives.

The authors of the study, having analyzed the legal norms and practice of the Regulations No.23 "The rules of internal order in the division of the place of confinement where the re-socialization program is implemented for the reduction of addiction" of the Cabinet of Ministers as of January 3, 2017, have found that neither the Sentence Execution Code of Latvia, nor Regulations No.23 of the Cabinet of Ministers as of January 3, 2017 stipulate neither the sentence of imprisonment execution regime requirements nor the re-socialization aspects of the newly established prison units. As previously indicated, in 2017, 22 convicted persons were released from the Center for drug addicts of Olaine city prison, either after the expiry of term of imprisonment or before expiry of the term of imprisonment. Most of the persons released from the places of confinement, after serving their main punishment, go to the further disposal of the State Probation Service, to ensure the supervision of probation service. The authors of the study, in their turn, in their analysis of further practice, find that the State Probation Service does not provide the addiction reduction programs to convicted persons, whose offenses were related to the use of narcotic and psychotropic substances, thus, the country does not have uniform systemic approach to risk reduction and prevention of new criminal offenses. Taking into account the above, the authors of the study conclude that in order to achieve the purpose of a punishment and to ensure public safety, it is necessary to organize the execution the sentence of imprisonment in such a way so that the execution of punishment and convicted persons' re-socialization measures would be coordinated and would interact with each other, thus 
contributing to the formation of a socially acceptable behavioral pattern of offenders that would allow them to successfully integrate into society in the future and prevent the recurrence of criminal offenses. The efficiency of addiction reduction programs of prisons will increase if persons, who have completed these programs, after release from prison, will also have special re-socialization support programs that would help the released persons to further restructure their lives, and would contribute to their normal functioning in society without the need for addictive substances.

\section{Conclusions}

Drugs are a threat to the security of any state, and they seriously endanger the development of society and cause irreparable harm to the health of the individual. The security of the community, into which persons, who have served their sentence will return, will largely depend on the effectiveness of the addiction reduction program. The security of the community has a positive impact on the existence, well-being and social security of each individual.

Upon the opening of the Center for drug addicts of Olaine city prison of the administration of the places of confinement, the policy of criminal punishments in Latvia and execution of a sentence of imprisonment in respect of convicts, who are addicted to narcotic or psychotropic substances, have undergone significant changes. The purpose of these changes is to reduce and to eliminate to the minimum the risk of addiction of these persons, and to teach them to live with this addiction problem, when returning into society after serving their sentence.

The established Center for drug addicts is a new facility and the addiction reduction programs are also, to a certain extent, still in the process of approbation, as approbation and completion of addiction reduction programs are essential for further successful implementation of these programs. During the process of approbation and completion of the programs it is necessary to find the main aspects of these programs that bring the best results. Negative experience is also an experience. The specific method or program will not always be equally effective for everyone. It is important not to stop at the achieved success and to periodically re-evaluate the achieved results, whether the implemented programs are effective and whether they deliver the desired result today, however, besides that, it is also important to evaluate the potential long-term result. When developing the new and improving the existing addiction reduction programs, the addicts themselves have to be listened to and their opinion must also be taken into account.

The authors of the study point to the fact that, in regard of assessment of the effectiveness of addiction reduction programs, the achieved qualitative indicators are more important than quantitative ones. It is essential for the state to establish a unified, strong, successive system for reducing the narcotic and psychotropic substances addiction in general, based on common principles, methodology and approach. There is no such system in Latvia yet, due to what a rhetorical question arises. What happens to such a person after his release from the place of confinement? Creating a unified state system for reduction of addiction, as one of the most important indicators of program efficiency, it is necessary to provide a feedback between the work done and resources, as well as the achieved practical results, and not just the indicative readings. Modern society expects from execution of a sentence of imprisonment that a person, after being released from the place of confinement, will not commit new offenses, and will be successfully integrated into society and the labor market.

The duty of every country, in respect of addiction reduction issues, is to create its own internal policy and intervention. When developing an addiction reduction policy, it must be based on scientific research and evidence. Unfortunately, it must be acknowledged that in Latvia there is no research on the circulation of narcotic and psychotropic substances in the places of confinement and the effectiveness of various addiction reduction programs. These studies should be included in the agenda of the administration of the places of confinement in the very near future. 


\section{References}

Atkarība un tās veidi. Atkarības profilakse un pal̄̄dzība. Portāls "Vesels rīdzinieks veselā vidē". [Addiction and its types. Prevention of addiction and the assistance to the addicted persons. Portal - "Healthy Rigan in a Healthy Environment]. Available on the Internet: http://www.veseligsridzinieks.lv/atkariba-un-tas-veidi

Atklās atkarīgo centru Olaines cietumā. Ieslodzījuma vietu pārvalde. [Opening of the Center for drug addicts of Olaine city prison. Prison Administration.]. Available on the Internet: http://www.ievp.gov.lv/index.php/33-jaunumi/aktualitates/121-brasas-cietum-nosldziesalfa-kurss

Broka, B. (2014). Tieslietu ministre: drošība cietumos atkarīga no katra ieslodzījuma vietas darbinieka. Tieslietu ministrija. Jurista vārds. 2014.gada 15. jūlijs.[Minister for Justice: Security in prisons depends on each employee of the place of confinement. Ministry of Justice.]. Available on the Internet: http://www.juristavards.lv/zinas/264851-tieslietu-ministre-drosiba-cietumos-atkariga-no-katraieslodzijuma-vietu-darbinieka/

Creteno, M. (2013). Interesantas iniciatīvas cietumu pārvaldī̌̌anā: no valstu praksēm līdz Eiropas vadlīnijām. Eiropas cietumu observatorija. Ieslodzījuma apstākḷi Eiropas Savienībā., Roma: izdevniecība “Antigone”, ISBN 978-88-98688-09-8. [Interesting initiatives in prison management: from national practices to European guidelines. European Prison Observatory. Prison conditions in the European Union, Rome: “Antigone” Publishing House]. Available on the Internet: http://cilvektiesibas.org.lv/site/attachments/06/01/2015/ CIETUMI_LABAS_PRAKSES.pdf

Ieslodzījuma vietu pārvaldes 2017.gada publiskais pārskats. Rīga: Ieslodzījuma vietu pārvalde. 2018. [Prison Administration Public Report, 2017. Riga: Prison Administration]. Available on the Internet: http://www.ievp.gov.lv/index.php/publikacijas/gada-publiskaisparskats

Kārtība un drošības pasākumi ieslodzījuma vietās. Cilvēktiesību gids. Ieslodzījuma vietas. [Order and security measures in the places of confinement. Human Rights Guide. The Places of Confinement]. Available on the Internet: http://www.cilvektiesibugids.lv/lv/temas/ ieslodzijuma-vietas/kartiba-un-drosibas-pasakumi-ieslodzijuma-vieta

Kḷave, E.; Bebriša, I.; Žabko, I.; Šūpule, I.; Jansone, L. (2014). Narkotiku izplatība ieslodzījuma vietās Latvijā 2014.gadā. Pētījuma gala ziñojums. Slimību profilakses un kontroles centrs. [Drug distribution in the places of confinement of Latvia in 2014. Final study report. Center for Disease Prevention and Control]. Available on the Internet: https://spkc.gov.lv/upload/Petijumi\%20un\%20zinojumi/ Atkaribu\%20slimibu\%20petijumi/narkotiku_izplatiba_ieslodzijuma_vietas_lv_2014_gada.pdf

Konference par dinamisko drošību. Ieslodzījuma vietu pārvalde. 2016. gada 10. novembrī. [Conference on dynamic security. Prison Administration. November 10, 2016]. Available on the Internet: http://www.ievp.gov.lv/index.php/131-konference-par-dinamiskodrosibu-cietumos

Koroḷeva, I.; Mieriņa, I.; Goldmanis, M.; Sniķere, S.; Trapencieris, M. (2007). ESPAD 2007 Atkarību izraisošo vielu lietošanas paradumi un tendences skolēnu vidu. Latvijas skolu aptaujas projekts par alkoholu un citām narkotiskajām vielām. Rīgā: Sociologisko pētîjumu institūts. ISBN 978-9984-837-03-1., p.65. [ESPAD 2007 Addiction causing substance use habits and trends of among students. Latvian school survey project on alcohol and narcotic substances. Riga: Institute of Sociological Research]

Koroḷeva, I.; Mieriṇa, I.; Goldmanis, M.; Trapencieris, M. (2008). Atkarību izraisošo vielu lietošanas izplatība iedzīvotāju vidū. Pètījuma rezultāti. Rīgā: Sociologisko pētījumu institūts. ISBN 978-9984-837-02-6-2, p. 67.[The prevalence of use of addictive substances among the population. Study results. Riga: Institute of Sociological Research].

Latvijas Sodu izpildes kodekss. LR likums. Ziṇotājs, 1971. gada 1. janvāri, Nr. 1. [Law On Sentence Execution Code of Latvia. The Law of the Republic of Latvia Zinotays. No.1, 01.01.1971]. Available on the Internet: http://likumi.lv/doc.php?id=90218

Luksa, M. (2015). Ar devīzi "Vienreiz programmā, nekad vairs cietumā". Latvijas Vēstneša portāls "Par LIKUMU un VALSTI". 2015. gada 27. augustā. [With the motto "Once in the program, never in prison". Web Portal Latvijas Vestnesis on Law and State. August 27, 2015]. Available on the Internet: http://m.lvportals.lv/visi/likumi-prakse?id=273308

Luste, M. (2014). Norvēégijas ārlietu ministrijas vizìte Latvijā par Atkarīgo centra būvniecību Olaines cietumā.. Jurista Vārds. 2014. gada 4. aprīlī. [Visit of the Norwegian Ministry of Foreign Affairs to Latvia regarding the construction of the Center for drug addicts of the Olaine city prison. Jurista Vards. 04.04.2014.]. Available on the Internet: http://www.juristavards.lv/zinas/264156-norvegijasarlietu-ministrijas-vizite-latvija-par-atkarigo-centra-buvniecibu-olaines-cietuma/

Luste, M. 2016. Krustpunktā. Ievads. Ieslodzijuma vietu pārvalde. [At the crossroads. Introduction. Prison Administration]. Available on the Internet: http://www.ievp.gov.lv/index.php/projektu-realizacija/norvegijas-finansu-instruments/projekts-jaunas-nodalas-izveideolaines-cietuma-ieskaitot-buvniecibu-un-personala-apmacibu/informacija-par-projekta-istenosanu/74-krustpunkta-ievads 
Ministru kabineta 2006. gada 30. maija noteikumi Nr. 423 „Brīvības atñemšanas iestādes iekšējās kārtības noteikumi”. Latvijas Vēstnesis Nr.86(3454) 2006. gada 2. jūnijā. [Regulations No.423 "The Rules of Internal Order of Penitentiary Institutions" of the Cabinet of Ministers as of May 30, 2006, Latviyas Vestnesis. 86 (3454), 02.06.2006.]. Available on the Internet: http://likumi.lv/doc. php?id=136495

Ministru kabineta 2017.gada 3. janvāra noteikumi Nr.23 “Iekšējās kārtības noteikumi brīvības atnemšanas iestādes struktūrvienībā, kurā tiek īstenota resocializācijas programma atkarību mazināšsanai”. Latvijas Vēstnesis Nr. 25 (5852) 2017.gada 1.februārī. [Regulations No.23 "The rules of internal order in the division of the place of confinement where the re-socialization program is implemented for the reduction of addiction" of the Cabinet of Ministers as of January 3, 2017, Latviyas Vestnesis. 25 (5852), 01.02.2017]. Available on the Internet: https://ikumi.lv/ta/id/288414-ieksejas-kartibas-noteikumi-brivibas-atnemsanas-iestades-strukturvieniba-kura-tiekistenota-resocializacijas-programma-atkaribu

Paparde, I. (2016). Olaines cietuma Atkarīgo centrs sāk darbu. nra.lv. 2016.gada 30. novembrī. [The Center for drug addicts of the Olaine city prison begins its work. nra.lv. November 30, 2016.]. Available on the Internet: http://nra.lv/latvija/regionos/193069-olainescietuma-atkarigo-centrs-sak-darbu.htm

Recommendation Rec (2006) 2 of the Committee of Ministers to member states on the European Prison Rules. Available on the Internet: http://www.coe.int/t/DGHL/STANDARDSETTING/PRISONS/EPR/Rec_2006_2Latvia.pdf

Semenkova, V. (2001). Ieslodzīto rehabilitācijas psihologiskēs problēmas. Administratīiā un Kriminālā Justīcija. Nr. 4(2001). Rīgā: LPA izdevums. ISBN 1407-2971, p. 26. [Convicted persons' psychological problems of rehabilitation. Administrative and Criminal Justice. No. 4(2001)].

Stivrenieks, M. (2016).Ispolnenie nakazanija v vide lishenija svobody v Latvii: teorija i praktika. Aktualnye problem prav liudini, jaka perebuvae v konflikty s zakonom, kriz prizmu pravovyx reform. Sbornik materialov mezhdunarodnoj nauchno-prakticheskoj konferencii (Kijev, 2 grudnja 2016) ISBN 978-617-7373-88-8. p. 8. [Execution of the punishment of imprisonment in Latvia: theory and practice. Actual problems of human rights, who is in conflict with the law, through the prism of legal reforms. The collection of materials of the international scientific-practical conference. Kiev, December 2, 2016].

Tuvinieku vizītes Olaines cietuma Atkarīgo centrā motivē gan klientus, gan darbiniekus. Ieslodzījuma vietu pārvalde. 2017. gada 11. jūlijā. [The visits of relatives to the Center for drug addicts of the Olaine city motivate both clients and employees. Prison Administration. July 11, 2017]. Available on the Internet: http://www.ievp.gov.lv/index.php/210-tuvinieku-vizites-olaines-cietuma-atkarigo-centra-motive-gan-klientus-gan-darbiniekus

United Nations General Assembly, Resolution adopted by the General Assembly on 17 December 2015, United Nations Standard Minimum Rules for the Treatment of Prisoners (the Nelson Mandela Rules). Available on the Internet: http://www.penalreform.org/resource/ standard-minimum-rules-treatment-prisoners-smr/

Zahars, V. (2017). Noziedzības ekonomiskie un sociālpsihologiskie determinanti. Mācību līdzeklis. Daugavpils Universitāte: Akadēmiskais apgāds "Saule". ISBN 978-9984-14-795-6. p. 7. [Economic and socio-psychological determinants of crime. Teaching Aid].

Zahars, V.; Stivrenieks, M. (2014). Security implementation facets: convicted women imprisonment sentence execution. Journal of Security and Sustainability Issues 3(3):45-53. DOI: http://jssidoi.org/jssi/papers/papers/view/161

Zahars, V.; Stivrenieks, M. 2015. Ieslodzījuma vietu drošības aspekti. [Security Aspects of the Places of Confinement]. Administratīvā un Kriminālā Justīcija. Nr. 1(70)/2015. Rīgā: Baltijas Starptautiskā akadēmija. [Administrative and Criminal Justice., No.1/2015 (70), p.39. Riga: Baltic International Academy Edition]. ISSN 1407-2971.

Zahars, V.; Stivrenieks, M. (2015). Security implementation facets: peculiarities of execution of the sentence of imprisonment in respect of convicted minors. Journal of Security and Sustainability Issues 4.3(3):221-231. http://jssidoi.org/jssi/papers/papers/bykeyword/177

Zahars, V.; Stivrenieks, M. (2016). Security and safety enforcement: execution peculiarities. Journal of Security and Sustainability Issues 6(1):71-83. DOI: http://jssidoi.org/jssi/papers/papers/bykeyword/177

Vitolds ZAHARS. Prof., PhD. iur., Head of Law Department of the Daugavpils University. Research interests: Criminal Justice, Penal Law, Sentence Execution Rights, Issues of State Security and Sustainability.

ORCID ID: 0000-0003-1100-0519

Maris STIVRENIEKS. Is a PhD candidate of the Daugavpils University, Deputy Director of Latvian Prison Administration. Research interests: Criminal Justice, Penal Law, Sentence Execution Rights, Issues of State Security and Sustainability.

ORCID ID: 0000-0002-1567-2083 
JOURNAL OF SECURITY AND SUSTAINABILITY ISSUES

ISSN 2029-7017 print/ISSN 2029-7025 online 